\section{OS RUMOS DA CIDADE: URBANISMO E MODERNIZAÇÃO EM SÃO PAULO}

Candido Malta Campos

São Paulo: Editora Senac, 2002.

\section{Telma de Barros Correia}

O livro Os rumos da cidade: urbanismo e modernização em São Paulo, do arquiteto Candido Malta Campos, surge como uma importante contribuição para a compreensão do papel de urbanistas e políticos nas transformaçóes do espaço desta cidade no período entre 1870 e 1945 . Produzido como tese de doutorado pelo programa de Pós-Graduação da Faculdade de Arquitetura e Urbanismo da USP - orientada pelo Prof. Dr. Philip Gunn -, o livro se baseia numa pesquisa ampla e incorpora análises acuradas. Entre as qualidades da obra estão a riqueza e diversidade das fontes consultadas, as ilustrações profusas e esclarecedoras (sempre tratadas de forma complementar e subalterna à narrativa), a densidade, rigor e profundidade das análises realizadas e a redação ágil, características que tornam a leitura de suas mais de 600 páginas tarefa instigante e agradável. $\mathrm{O}$ livro baseia-se em trabalho de pesquisa histórica que concilia a leitura de uma vasta bibliografia sobre o tema a um amplo trabalho com as fontes - artigos, transcrições de conferências, leis, pareceres, discursos, mapas e fotos - dialogando com este material e, a partir dele, construindo uma narrativa bem estruturada.

Trata-se de uma abordagem abrangente que recupera e articula aspectos relevantes das transformações pelas quais passaram a cidade de São Paulo - especialmente sua área central - ao longo do período em análise. Analisa a gestação e o conteúdo de projetos urbanísticos e de instrumentos intervencionistas ou reguladores (códigos de obras, zoneamentos, normas de parcelamento, taxas de melhoria etc.). Investiga de forma minuciosa a evolução e maturação de propostas e a maneira como foram eventualmente implantadas. Desvenda a diversidade das propostas formuladas em meio a diferentes posturas, divergências teóricas e distintas filiações. Indica as referências internacionais e nacionais mobilizadas nas diferentes propostas e a forma como se procurou adequá-las às condiçôes locais. Os elos entre modelos urbanos e arquitetônicos - vinculados a voca- bulário eclético, beaux-arts, neocolonial ou "moderno monumental" - são enfatizados e discutidos.

A obra salienta o papel relevante desempenhado na conformação do espaço da cidade por políticos, entre os quais, João Alfredo, Fábio Prado e Gofredo Teles; por engenheiros, arquitetos e urbanistas - como Vítor Freire, Saturnino de Brito, Ricardo Severo, Bouvard, Ulhoa Cintra e Artur Sabóia; e por personagens que atuaram nos dois campos de atividades - como Heribaldo Siciliano, Alexandre de Albuquerque, Pires do Rio, Anhaia Melo e Prestes Maia.

$\mathrm{Na}$ sua conclusão, ao tecer considerações sobre a configuração atual de São Paulo, o autor assinala que "o modelo que persiste na cidade não é único nem inevitável, tendo resultado dos embates em torno da modernização urbana ao longo do século passado" (Campos, 2002, p.631). O grande mérito de sua obra é precisamente desvendar aspectos desses embates. $\mathrm{O}$ autor mostra como nessas disputas vão estar envolvidas demandas simbólicas, estéticas, higienistas, de tráfego, de valorização imobiliária e interesses políticos e comerciais. Confrontos, debates e busca de soluções alternativas, muitas vezes conciliatórias, marcaram a trajetória de projetos e propostas, e vão contrapor urbanistas, políticos e técnicos dos setores de obras públicas, cujas posições são defendidas em artigos, conferências, cursos e em propostas de intervenção no espaço urbano. Dois aspectos destes embates são enfatizados ao longo do livro: o confronto entre projetos diversos e o relativo descompasso entre projetos e realizações.

Em termos da convivência e concorrência entre orientaçóes e projetos diversos, uma das questóes enfatizadas refere-se às diferentes formas de apropriação e assimilação de experiências e modelos internacionais. A esse respeito mostra-se, por exemplo, como nas primeiras décadas do século XX modelos de inspiração "hausmannianas" - então privilegiados nas intervenções urbanísticas nas capitais nacionais - chocaram-se com padrões de inspiração "sittiana", defendidos por urbanistas como Vítor Freire e Saturnino de Brito. Demonstra-se também como a ênfase das propostas urbanísticas foi se deslocando de questôes sanitárias para preocupações viárias, num movimento que redefine inclusive os padrōes estéticos eleitos e o lugar de preocupaçōes desta natureza nos planos. Recupera-se o debate entre propostas que buscam conter o crescimento da cidade - defendidas por Anhaia Melo - com outras 
que pressupóem um crescimento ilimitado, que tiveram em Prestes Maia um representante. Assinala-se o conflito entre o padrão urbanístico dos bairros-jardins e os modelos de vias retilíneas e largas consagrados nos códigos das primeiras décadas do século $\mathrm{XX}$, além dos embates entre defensores e críticos da verticalização do centro da cidade, e entre propostas de criação de grandes avenidas por meio do alargamento de vias existentes ou criação de novas vias em fundos de vale.

Ao assinalar o descompasso entre planos e intervençôes, o autor contrapóe ao teor e a amplitude dos projetos as características e o caráter parcial das realizações. Mostra o limite geográfico restrito atingido pelas reformas urbanas do início do século XX. Citando instrumentos como as taxas de calçamento e a contribuição de melhoria, indica a dificuldade encontrada de pôr em prática medidas amplamente defensáveis em termos conceituais. Referindo-se aos casos dos urbanistas Anhaia Melo e Prestes Maia, mostra os limites da aplicação de muitas das ditas "soluções racionais" recomendadas por urbanistas, que não conseguiram efetuálas mesmo quando prefeitos da cidade. Tal descompasso evidencia não apenas limitações orçamentárias, como também a busca em conciliar a ação pública com interesses locais. Ao analisar a trajetória entre a formulação das propostas urbanas e a eventual intervenção, Campos evidencia os ajustes introduzidos e as negociações efetivadas que buscavam conciliar interesses diversos de setores do capital, de valorização fundiária, de reprodução da força de trabalho e de legitimação dos dirigentes. Analisando este percurso entre proposiçōes e açôes, o autor salienta como "o processo de intervenção urbanística, longe de ser mero campo de progresso técnico, implicava opções com sérias conseqüências sobre as condições de vida, acumulação e produção vigentes no centro urbano" (Campos, 2002, p.283).

Em meio a tais embates, o autor assinala o delineamento de algumas tendências, entre as quais a mais nítida é a crescente ênfase das intervenções - em especial a partir da década de 1920 - nas questóes referentes a tráfego e sistema viário. Tal ênfase ocorre em detrimento de outras demandas - estéticas, habitacionais e de lazer - e se direciona, sobretudo, ao estímulo do transporte particular e do ônibus entre as modalidades de transporte coletivo. O Plano de Avenidas - concebido por Prestes Maia no final da década de 1920 surge como um momento exemplar desta tendência.
Ao final de sua análise, Campos salienta o poder de permanência da visão expansionista e "rodoviarista" de Ulhoa Cintra e de Prestes Maia, enumerando intervençôes recentes na cidade de São Paulo que concretizam diretrizes do Plano de Avenidas, como a passagem subterrânea da avenida Tiradentes, que integra o perímetro de irradiação e túneis e vias ligando as avenidas Bandeirantes e Salim Maluf, que integram o terceiro circuito perimetral.

Ao tratar a cidade de São Paulo como um campo de disputas entre idéias, práticas e projetos urbanísticos, que contrapõem concepções que afetam interesses diversos, o livro desvenda o papel central de urbanistas que atuaram no período em análise na mediação de conflitos de interesses e de visões de cidade. Analisando esta atuação, mostra como o domínio de técnicas, o conhecimento de experiências internacionais e uma suposta neutralidade fundamentada numa pretensa racionalidade foram instrumentos importantes. Mas, o grande mérito da obra é precisamente sublinhar o vasto campo de lutas - tantas vezes escamoteado em abordagens restritas a aspectos formais - que permeia o pensamento e a prática do urbanismo.

\section{CIDADES ESTREITAMENTE VIGIADAS: O DETETIVE E O URBANISTA}

Robert Moses Pechman

Apresentação de Stella Bresciani

Rio de Janeiro: Casa da Palavra, 2002.

Amilcar Torrão Filho

Clarice Lispector escreveu em uma crônica que, quando criança, acreditava que os livros nasciam em árvores. Hoje sabemos que eles têm autores e são resultado de muito trabalho e de um esforço de imaginação. Há ainda aqueles que são escritos inspirados em outros livros, que lhes abrem o caminho ou servem como fonte de informação, estímulo ou inspiração. É este o caso de Cidades estreitamente vigiadas: o detetive e o urbanista, de Robert Moses Pechman, inspirado que foi pela leitura de um pequeno livro já tornado um clássico. Considera-se o autor uma destas pessoas a quem, por defeito de fabricação, os "livros desequilibram, produzem abismos, causam estragos, torcem a vontade, 